\title{
CUSTOMERS' PERCEPTIONS OF MOBILE BANKING USING THE TECHNOLOGY ACCEPTANCE MODEL FOR SELECTED BANKING OUTLETS IN GAUTENG, SOUTH AFRICA
}

\author{
By \\ Prof. Ajay K Garg \\ 159 Skinner Street, TUT University, Pretoria \\ E-mail: Gargak@tut.ac.za; akg20055@yahoo.co.in \\ Mrs. D. Garg \\ University of Botswana, Gaborone \\ Mr. K.S. Ledwaba, \\ TUT Business School, Pretoria.
}

\begin{abstract}
Much of the available literature that has examined the diffusion of mobile banking has tended to focus on the developed societies where these innovations had initially been introduced. As such, there is a paucity of studies on the diffusion of innovations that have focused on mobile banking in developing contexts generally and in particular in South Africa. This study focused on convenience, cost/price, trust and the original variables of the extended technology acceptance model by Venkatesh and Davis. The study has further explored the main influencers for mobile banking among customers on the basis of their perceptions of important attributes of the electronic banking technology.
\end{abstract}

Key words: Mobile banking; South Africa; TAM; Customer perceptions.

\section{Council for Innovative Research}

Peer Review Research Publishing System

Journal: INTERNATIONAL JOURNAL OF COMPUTERS \& TECHNOLOGY

Vol. 13, No. 1

editor@cirworld.com

www.cirworld.com, www.ijctonline.com 


\section{INTRODUCTION}

Mobile banking (M-banking) is still in an infant stage, particularly in most developing countries like Brazil, Asia and South Africa, hence there is a scarcity of research work done on mobile banking in Africa in general and in South Africa in particular. Since its introduction, mobile banking users have been able to use this added service to obtain special services 24/7 without having to go physically to braches of the traditional bank for their banking services [1].

South Africa has a successful, growing economy and its telecommunication industry is in an advanced stage. Since June 2011, about $144 \%$ of cell phone penetration has been reported [2] and this number is set to rise even further. About eight million smart phones and tablets are in circulation today and these are likely to increase mobile banking platforms for banking customers. In South Africa $16 \%$ of banking customers use the internet for banking, $28 \%$ use their cell phones and a total number of $34 \%$ of them use one or both of these channels.

ATM usage from 2005 to 2011 has decreased dramatically from $24.4 \%$ to $14.2 \%$ [2] and this drastic drop is attributed to number of factors including: ATM bombing (safety), banking sector legislation, customers to personal banking and more importantly, the introduction of mobile banking. A large number of people still use the traditional method of banking, which is visiting the banking branch physically for banking activities like transferring money, requesting mini-statements. Some people still travel long distances to buy airtime and to play Lotto instead of using mobile banking.

Mobile banking is currently implemented through the use of two different technological solutions namely Wireless Access Protocol based (WAP) internet access and cell phones with an embedded chip-set [3]. Mobile banking has the potential to change many people's lives by bringing banking services into their hands and to their door-steps. It offers effective, convenient, safe and low-cost banking transactions, but for it to be widely used by many South Africans, it has to be generally known and accepted. Banks are also embracing mobile banking to focus and capitalise on emerging opportunities and to supplement traditional off-line, packed banking branches and phone banking [4].

The main reason behind this study is driven by the latest technological developments and innovations by many financial institutions such as banks. The main purpose of this study was to investigate customers' perceptions of the use of mobile banking in Gauteng, South Africa.

\section{LITERATURE REVIEW}

Several authors $[5,6]$ define mobile banking as use of mobile phones for banking actions by individuals. The internet and mobile internet banking services are the latest, most innovative and most profitable banking services to be offered by the banks. As opposed to this, the traditional types of products and services that are driven by technology, such as credit cards, automatic teller machines (ATMs), telephone and television banking are some of the technology-based service innovation that have been offered by banks to overcome the drawbacks of changing market conditions [7]

Cell phones are rapidly becoming a reasonable alternative to personal computers (PCs), because mobile devices in the form of cell phones, smart phones (including Blackberries and iPhones), Pocket PCs, tablet PCs and multimedia readers with wireless connections (or any other way of connecting to online banking services) are found to be effective and convenient customers. Furthermore, it has been found that one requirement for mobile banking is that a customer should have a bank account in order to use the service, and be a registered mobile and online banking customer.

According to $[8,9,10,11]$ the advantage of mobile banking is its convenience in that it offers, cheap, faster and easier access to banking, no matter what the location or time and that it is efficient. Furthermore, mobile banking drastically cuts down the cost of providing a service to the customers. Most people now realise that mobile phones have economic benefits for customers' especially in remote places where roads are bad and there are few trains or taxis.

Additionally, this mobile banking could save customers money in terms of taxi fares, petrol and time spent driving to a bank.

Despite the above-mentioned benefits of using mobile banking, some researchers have highlighted a number of limitations or concerns with regard to the product. One of them is that banking customers cannot arrange for stop orders through mobile banking. Concerns have also been raised over password integrity, privacy, data-encryption, hacking and the protection of personal information [12]. Another challenge is that mobile devices with small screen sizes, limited screen resolution and unrecoverable key words may make it difficult for some customer to use mobile banking [13]. Further mobile banking is vulnerable to an information and transaction eavesdropping risk, just like other e-commerce applications such as internet banking [7].

\section{Adoption of mobile banking}

Mobile banking, particularly in Africa has been derailed by two major barriers to its penetration of the untapped market. They are (i) related uncertainties about customer adoption, (ii) specific regulatory issues such as remote customer due diligence requirements and access to the payment system. Rogers [14] found that usage barrier which comes into operation when an innovation is not compatible with existing workflows, practices or habits.

For customers to adapt to a new system; it must free of defects, user-friendly, of a good quality, simple and its contents must be understandable. The following barriers have been identified that contribute to peoples' resistance to the adoption and the use mobile banking. 
-Psychological barriers refer to the tradition barriers and image barriers. According to $[15,16]$ it has been found that image plays an important role whether negatively or positively in influencing customers to use or adapt to new technology. Factors like the product image, company name and brand, country of origin of the product or difficulties in accessing new technology might also become obstacles to consumers' adoption of new products.

-Functional barriers refer to usage barriers, value barriers and risk associate barriers. Usage barriers occur when a technological innovation does not fit with users' workflows, habits and practices as more effort will be required from the user to learn and utilize the technological innovation [17]. However this construct is comparable to complexity which relates to the degree to which an individual considers an innovation to be relatively difficult to understand and use.

As states above a number of studies also found trust and perceived risks to have a significant positive influence on commitment $[18,19,20]$. A lower usage of mobile banking in countries like Korea, Finland and Taiwan, due to security concerns has been noted $[13,15]$. On the other hand, some authors argue that security concerns are not a prohibitive factor $[8,15,21]$.

Conversely, [22] claim that the most important factors that would encourage the use of mobile banking, would be through lower fees and improved levels of service, while also stating that there are some reasons for consumer's reluctance to use mobile banking services namely security and trust concerns, a lack of awareness on online services offered by banks complex bank sites, fraud and banking scams.

However, with regard to new technology acceptance, the literature points out that unless specific needs of consumer are fulfilled, they may not be prepared to change present familiar ways of operating, such as traditional banking [23]. This will depends on consumers' attitude towards adapting to new technology. Meuter [24] found that if a technological performance exceeds consumer's expectations, it has advantages over interpersonal service, and consumers. In difficult times, consumers are likely to evaluate the technology-based self-service favourably, and, as a result, are likely to be satisfied and happy to opt to use the product. $33 \%$ of consumers surveyed had never used a computer before, while 32 $\%$ felt intimidated when attempting to use a computer without help or prior experience [25]. Furthermore, attitude is an antecedent to intentions to adopt computer technologies. It can be concluded from the above information that attitudes to using technological products in general may provide insight why some consumers do and other do not adopt computer technology [26].

In concluding, it is evident that mobile banking is the latest technological development in electronic commerce (ecommerce), and of financial institutions (banks). There is little available literature and research done in South Africa in particularly, and Africa in general about the topic of mobile banking. The available literature about mobile banking has been found mostly in European and Asian countries. Despite this, it is evident that mobile banking offer enormous advantage to customers' such as anytime and everywhere.

\section{RESEARCH DESIGN AND METHODS}

\section{Research objectives:}

Mobile banking was introduced in South Africa in 2005, but South African bankers are still reluctant to adopt it. Therefore this study sought to investigate and determine their perceptions of South African bankers, their challenges they face and factors that contribute to the adoption of the new technology system of mobile banking.

The main purpose of this study was to investigate customers' perceptions of the use of mobile banking in South Africa. It aimed at identifying and analysing factors that influence South African consumers' adoption of mobile banking. Furthermore the study extended the basic TAM model with three key external variables that have been identified to have a positive influence on the adoption of mobile banking, namely: convenience, cost and trust [27].

This study used the well known Technology Acceptance Model (TAM), which has been found to be a practical utility for service developers, to explore the factors that affect customer's behavioural intentions to use information technology and computer systems through the use of the two variables, namely: perceived ease of use and perceived usefulness [26].

The sections below discuss the instrument used, questionnaire design, data collection etc.

\section{Questionnaire design}

The study used a structured questionnaire. The questionnaire was divided into three sections. Section A-covered demographic information, Section B-involved the use of mobile banking and Section C contained TAM related questions. A five point Likert scale rating was used. Section B of the questionnaire was aimed at inquiring about customer's background on the usage of mobile banking. In this section the questions were based on their respondents experience and knowledge of mobile banking. The questions asked included, whether respondents had a cellular phone, an account number, how much time do they spent on travelling to the nearest bank or branch for their banking services, whether respondents had or used mobile banking facilities and if so, what do they used mobile banking for buying airtime, buying pre-paid electricity, pay beneficiaries, and to transfer money from one account to another, obtaining account information, pay store accounts and ordering cheque books. Furthermore, some of the questions were about the amount respondents spent monthly on the use of mobile banking through data bundles, monthly subscriptions, contracts, the use of a cell phone as a modem, or just through cellular phones. In order to know which network attract more mobile users, a question was posed about which mobile banking service provider customers use or prefer. 
Section C contained questions related to TAM. Table 1 shows the construct, variables and indicators used in the questionnaire based on the past researchers.

TABLE 1. Survey questionnaires statements related to variables:

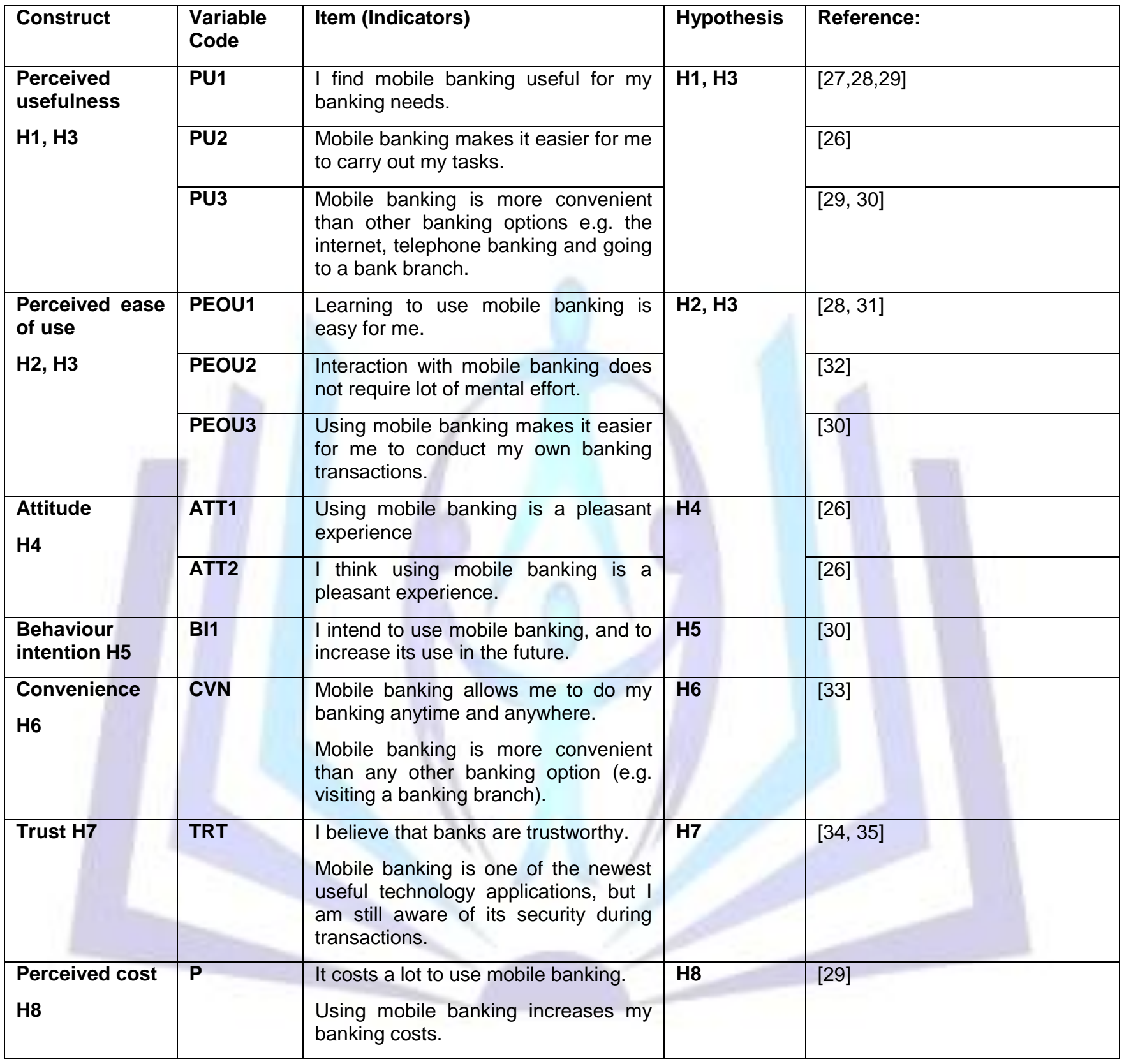

The design of the questionnaire was taken from the literature and other studies, therefore, its validity and reliability had already been established and assured.

\section{Sample size}

For the purpose of this study, the population target was ordinary South Africans in Gauteng province who have a cellular phone and bank account use mobile banking for their banking activities, and have an income level of R3 000 per month or above. The respondents were targeted from the four largest banks in South Africa, namely: First National Bank (FNB), Absa, NedBank and Standard Bank in the cities of both Johannesburg and Pretoria. The sample was randomly selected from the total number of targeted respondents.

\section{Pre testing}

A pre-testing (pilot study) was conducted on the questionnaires to validate and check question and to verify that they have been clearly phrased if questionnaire questions have been clearly and unambiguously phrased and also to determine the 
time it takes for participants to complete the questionnaire, and to determine if the wording of the questions was clear. Pre-testing was conducted through TUT employees.

\section{Administering the questionnaire}

The study used the self-administered questionnaire approach to deliver and collect questionnaires, particularly at banks and participants targeted at shopping malls and banks. This method was found to be effective because all questionnaires were properly completed and returned immediately by participants. The other method used was the email based questionnaire approach which was inexpensive, and effective. Questionnaires were sent to participants and different companies by email. The respondents completed and returned them by email in the allocated time.

Participation was voluntary and respondents were given three to five working days to reply or return the questionnaire. A due date was given to all participants and close to the due dates participants were sent emails to remind them to complete the questionnaires and return them. Only ten questionnaires from the total of 210 were not returned. A total of 200 questionnaires were returned.

\section{Ethics}

In this study, participants were informed of the nature and the benefits of the study to be conducted and assured of their privacy, anonymity and confidentiality. They were assured that their responses would be treated with respect and integrity and they were given the choice to participate or not to participate. Furthermore, participants were given the option to participate or to withdraw from the research study if they felt uncomfortable. About 200 participants took part in this study and were well informed about ethics in the study. All the above ethical issues were observed when the research study was conducted.

\section{Research model and hypothesis}

\section{Hypothesis:}

The literature review provided evidence of and support for the relevance and the significance positive effect of PU on the consumer usage intention of mobile banking [1,30]. Perceived Usefulness (PU) is defined "as the degree to which a person believes that using a system will enhance his or her job performance" [28]. The main reason why people exploit mobile banking is because they find it convenient and useful. Therefore, we tested the following hypothesis:

\section{HI: To determine if PU has a positive influence on consumers' use of mobile banking.}

PEOU has a significant effect on consumer usage intention of the system or mobile banking whether it affects PU directly or indirectly [30]. PEOU refers to the cognitive effect that an individual puts forward in learning the technology. Customers expect mobile banking to be easy to use [31]. A complex system of mobile banking might act as a barrier to consumers' adoption of mobile banking. Therefore, PEOU has been identified as positively predicting South African consumers' attitudes towards the use of mobile banking.

PEOU is a determinant of the adoption of mobile banking, hence functionality features like screen size, and type of keypad can be considered the contributory factors to ease of use $[13,36]$. PU and PEOU are the main determinants of the behaviour intention $(\mathrm{BI})$ [1]. This means that PEOU influences attitudes and behaviour intention. In this study it is hypothesized that PEOU would have a positive effect on consumers' behaviour intention. Therefore, the following hypothesis was tested:

\section{H2: To determine if PEOU has a positive influence on consumers' adoption of mobile banking.}

Prior studies have defined PEOU "as the degree to which the person believes that using a system of mobile banking will be free of effort" [28]. Both PEOU and PU have been found to have a central influence to consumers' use and adoption of mobile banking. They are referred to as the determinants of behaviour intention [1]. Perceived usefulness has been found to directly influence behaviour intention, while perceived ease of use was indicated to have a direct or indirect effect through perceived usefulness or behaviour intention. Therefore, the role of attitude is central in this case to influence consumer's adoption of mobile banking. The hypothesis was formulated as follows:

\section{H3: To investigate if PEOU has a significant influence on PU in influencing consumers to adopt mobile banking.}

Several authors [26, 37] define attitude as "the driver of consumer utility or attributes (negatively/positive behaviour) towards technological innovation adaptation". System adaptation is determined by perceived usefulness and perceived ease of use which are related to attitude and thereby to the actual usage of the system of mobile banking. Therefore, our hypothesis was: 


\section{H4: To investigate if consumers' attitude (A) has a positive influence on BI or Consumers' actual usage of mobile banking.}

Behaviour intention is responsible for a large part of behaviour variance, because it makes it possible to predict specific behaviours based on intention to perform the behaviour. For the purpose of this study, behaviour intention is referred as the intention that consumers have to adopt or continue using mobile banking. It projects, measures and validates in order to maintain current use and usage frequency. Therefore, we tested the following hypothesis:

\section{H5: To investigate if PU has a positive effect on Bl/actual usage in influencing consumers' usage of mobile banking.}

Convenience is defined "as an advantage that customers' associate with regard to the use of online banking and further appreciated by them" [38]. Mobile banking gives customers a convenience because it is not restricted of the time and the place [1], and to conduct their banking transactions anywhere and anytime, privacy and saving time and effort [21].

In this context of this study, the perceived convenience has been hypothesized as follows:

\section{H6: To investigate if there is a positive relationship between convenience and PU.}

According to a study [39] trust is defined as a feeling of security and willingness to depend on someone or something. In this study, trust of the system or mobile banking is hypothesised to have a positive influence on consumers' use of mobile banking. The higher the level of trust in a service provider leads to a greater the intention on the part of user to engage in mobile banking transactions [35]. Further trust refers as a psychological expectation that a party or a person will not behave opportunistically, but will rely on the system to be safe [13]. Trust refers to "an individual belief that others will behave based on an individual expectation" [40]. If customers fear to use the system, including fear of lack of standards for secure payment, lack of profitable business models, and consumers' fear of distributing their personal data, they will probably not adopt and trust mobile banking [34].

Trust helps to decrease these fears and facilitate transactions in e-commerce by reducing fraud, uncertainties and potential risks [34, 41]. Based on the research done [42] perceived trust is defined as the extent to which a person believes that using mobile banking will be free of security and privacy threats. Consumers will perceive the system to be easy-to-use mobile banking when users' have previous knowledge of how to use banking services [34]. Based on this, we have formulated our hypothesis as follows:

\section{H7: To investigate if there is a positive relationship between trust and PU.}

Perceived financial cost inhibits the use and adoption of mobile banking services [27, 43]. Perceived cost is defined as "an extent to which a person believes that he or she has required financial resources (for example money to pay for the handset and subscription) [27].

These costs may include cost related to transactional cost such as mobile device cost, bank charges and mobile network charges for sending communication traffic (including SMSes or data) and the subscription fee for using mobile banking.

Financial cost considerations might influence consumers' behaviour intention to use or not to use mobile banking. Furthermore, perceived financial cost is a significant antecedent of the behaviour intention to mobile banking. If the use of mobile banking is more costly or expensive to consumers, this might become a deterrent or a cost barrier to consumers and might affect their adoption and use of mobile banking. Perceived cost is normally regarded as a major concern when a new technology is first introduced [44]. Additionally consumers' income level or the affordability of the services will determine or influence their use of mobile banking. Especially when there is an emergent need or sudden need, the utility benefits might outweigh the cost issue. Thus, we tested the following hypothesis:

H8: To investigate if there is a positive or negative relationship between cost/price and PU. 


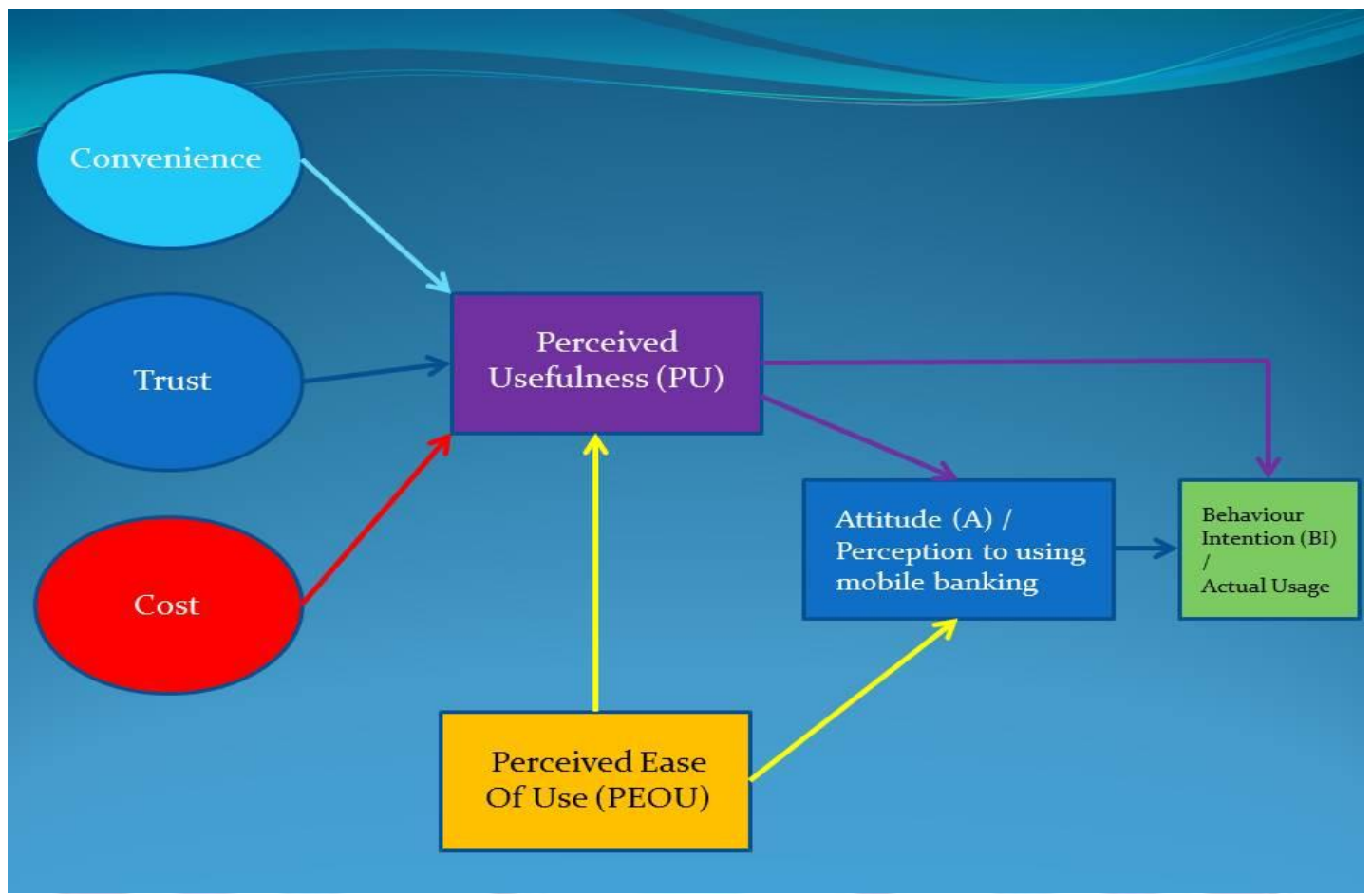

Figure 1. The proposed model

\section{Data analysis and results}

The multiple-response method of coding was used to code the collected data. It uses the same number of variables as the maximum number of different responses from any one case. The data received was coded (questionnaire numbered) and captured on an Excel spreadsheet. The section of the questionnaire containing TAM-related questions was analysed through partial least square (PLS).

\section{Research results}

\section{Demographic findings -}

\section{Age and gender}

A total of $57 \%$ were males and the females represented $43 \%$ of the respondents. The largest group fell in the age group $31-40$ years $(44 \%)$, the age group $20-30$ years represented $24 \%$ of the respondents and the age group $41-50$ years represented $22 \%$, while $10 \%$ were aged between 51 years and above.

\section{Marital status, education level and ethnicity}

Of the 200 completed questionnaires received, 123 (62\%) were from married participants, this number far outweighed the single or unmarried respondents. Only $75(38 \%)$ of the respondents were single. In terms of education and qualification level $42 \%$ of the respondents had degrees. A total of $37 \%$ of the respondents had postgraduate qualification whereas the undergraduate category recorded a low percentage of $21 \%$. This group can be referred as the middle class group of the total population of the country and fall in the Life Style Measure (LSM) of 5-10. Blacks/African participants consistently outnumbered other ethnic group categories. A total of $81 \%$ were blacks/African, $9.5 \%$ were whites, $5 \%$ were Indians and $4 \%$ were coloureds, while $0.50 \%$ was foreigners.

\section{Income level of participants}

Participants were asked to reveal their income level in the questionnaire. $40 \%$ had an income level above R20 000 per month. The second largest income category of 18\% participants were for people earning between R15000 and R20 000 per month. The third average group or category were for people earning between R10 000 to R15 000 with a $17 \%$ participants and 14\% were in the income group of R5000-R10000. For the income group between R3000 to R5000 per month the results reveal $4 \%$ participants. Whilst the lowest paid group of the category is for participants earning below or less than R3000 per month with a $7 \%$.

\section{Mobile banking results - use of mobile banking etc.}

In this section of the questionnaire participants were asked questions related to mobile banking, for example whether had a cellular phone, and whether they had a bank account and whether they did use mobile banking.

The vast majority of participants $99 \%$ had cell phones while only two (1\%) did not have cell phones. Vodacom was the most preferred service provider at $59 \%$. The results further revealed that the majority of the participants in this study have 
bank account with a recording high percentage of $99 \%$. Out of the200 participants $67 \%$ participants used mobile banking and only $33 \%$ did not use mobile banking transactions.

The results show that the majority of the participants spent less than 30 minutes to their banks for banking activities with $73 \%$ of participants. $23 \%$ of participants take between 30 minutes and 1 hour to their nearest banks. A total of $4 \%$ take more than an hour to the bank. This indicates that that most people are close to their banking branches or take less than an hour for them to reach their banks.

The results indicate that $19 \%$ of participants used mobile banking to buy pre-paid airtime while $18 \%$ of participants used mobile banking to transfer or pay beneficiaries. The results further reveal that $18 \%$ of participants used mobile banking to check their monthly mini-statements. Out of this number, $15 \%$ use mobile banking for account information, whereas $9.5 \%$ use it to pay store accounts. Only $8 \%$ use it to buy pre-paid electricity $6 \%$ use it for cash withdrawals and $4 \%$ use it to play the Lotto.

The data clearly reveals that of participants $43 \%$ spent less than R200 per month on mobile banking to do their banking activities. Participants who spent between R201 and R400 per month accounted for $27 \%$ of the respondents. Participants who spent between R401 and R600 per month accounted for $15 \%$. Only $6 \%$ of participants spent between R601 and R800 per month to stay connected while doing their mobile banking. It is evident in this study that a low number $9 \%$ of participants spent more than $\mathrm{R} 800$ per month on their mobile banking.

The results reveal that about $65 \%$ of mobile bankers stays connected for less than 30 minutes while doing their mobile banking activities through their phones. People who stayed connected for an hour accounted for $23 \%$. Participants who stayed connected for $1 \mathrm{~h} 30$ minutes and above 2 hours have recorded between $8 \%$ for $1 \mathrm{~h} 30$ and $2 \%$ for both who stays connected for an hour and more.

\section{ANALYSIS AS PER TAM MODEL-PARTIAL LEAST SQUARE}

The last part of the questionnaire deals specifically with investigating customers' perceptions of mobile banking, their attitudes towards it; it's their perceived usefulness, perceived ease of use, convenience, perceived trust and cost. The data of the Technology Acceptance Model was analysed through a Partial Least Square (PLS) version 3.00, build 1016 (1993-2003).

The results of the factor analysis are reported in Table 2 below:

\begin{tabular}{|c|c|c|c|c|c|c|c|}
\hline & PU & ATT & PEOU & BI & CVN & TRT & COST \\
\hline PU1 & 0.886 & 0.616 & 0.650 & 0.453 & 0.465 & 0.492 & -0.169 \\
\hline PU2 & 0.904 & 0.594 & 0.654 & 0.488 & 0.538 & 0.417 & -0.134 \\
\hline PU3 & 0.778 & 0.583 & 0.549 & 0.428 & 0.453 & 0.453 & -0.082 \\
\hline ATT1 & 0.359 & 0.720 & 0.388 & 0.363 & 0.356 & 0.426 & -0.007 \\
\hline ATT2 & 0.720 & 0.915 & 0.674 & 0.536 & 0.580 & 0.523 & -0.206 \\
\hline PEOU1 & 0.553 & 0.496 & 0.846 & 0.368 & 0.433 & 0.508 & -0.080 \\
\hline PEOU2 & 0.704 & 0.673 & 0.914 & 0.443 & 0.562 & 0.577 & -0.186 \\
\hline $\mathrm{Bl1}$ & 0.499 & 0.493 & 0.386 & 0.930 & 0.439 & 0.398 & 0.005 \\
\hline $\mathrm{Bl} 2$ & 0.497 & 0.552 & 0.479 & 0.938 & 0.600 & 0.473 & -0.151 \\
\hline CVN1 & 0.550 & 0.602 & 0.564 & 0.520 & 0.899 & 0.414 & -0.103 \\
\hline CVN2 & 0.382 & 0.355 & 0.373 & 0.407 & 0.776 & 0.340 & -0.127 \\
\hline TRT1 & 0.369 & 0.445 & 0.471 & 0.286 & 0.355 & 0.695 & -0.137 \\
\hline TRT2 & 0.333 & 0.301 & 0.318 & 0.310 & 0.280 & 0.707 & -0.054 \\
\hline TRT3 & 0.475 & 0.534 & 0.577 & 0.442 & 0.379 & 0.848 & -0.158 \\
\hline Cost 1 & -0.127 & -0.138 & -0.150 & -0.071 & -0.099 & -0.131 & 0.904 \\
\hline Cost2 & -0.149 & -0.150 & -0.141 & -0.077 & -0.142 & -0.162 & 0.932 \\
\hline
\end{tabular}

TABLE 2: Factor loading and cross loading of measures for the constructs Perceived Usefulness, Attitude, Perceived Ease of Use, Behaviour Intention, Convenience, Trust and Cost/Price 
Examination of factor loadings in Table 2 suggests that there was no major multicollinearity between the indicators, as the loading of the indicator with respect to its construct is greater than the other constructs. PU2, ATT2, PEOU2, BI1, BI2, Cost 1 and 2 have shown some collinearity with some variables loading at greater than 0.70 . To determine internal consistency and discriminant validity, the constructs were joined in the model, and the model was run as a molecular model. The results are shown in Table 3, which shows the correlation matrix for the construct where the diagonal of this matrix is the square root of AVE. The results shown in Table 3 below suggest good internal consistency, and convergent and discriminant validity for all the constructs with AVE greater than 0.50 of 0.65 (the decision rule is that AVE should be greater than 0.5 , which means that $50 \%$ or more of the variance of indicators should be accounted for). However, it should be noted that PU has an AVE of 0.36 and Trust with AVE of 0.31 and this may suggest a few things that will need to be looked into. These two constructs or variables are below the required $50 \%$ of the variance indicators in order to be validated.

\begin{tabular}{|c|c|c|c|c|c|c|c|c|c|}
\hline \multicolumn{8}{|c|}{ Correlation of construct } & \multirow[t]{2}{*}{ AVE } & \multirow[t]{2}{*}{ Fornell } \\
\hline & PU & ATT & PEOU & BI & CVN & TRI & COST & & \\
\hline PU & 0.86 & & & & & & & 0.36 & 0.89 \\
\hline ATT & 0.697 & 0.82 & & & & & & 0.54 & 0.81 \\
\hline PEOU & 0.722 & 0.674 & 0.88 & & & & & 0.59 & 0.87 \\
\hline $\mathrm{Bl}$ & 0.533 & 0.56 & 0.465 & 0.93 & & & & 0.69 & 0.93 \\
\hline CVN & 0.567 & 0.59 & 0.572 & 0.558 & 0.84 & & & 0.55 & 0.83 \\
\hline TRT & 0.529 & 0.579 & 0.619 & 0.468 & 0.452 & 0.75 & & 0.31 & 0.80 \\
\hline COST & -0.151 & -0.157 & -0.158 & -0.081 & -0.133 & -0.16 & 0.91796 & 0.65 & 0.91 \\
\hline
\end{tabular}

TABLE 3: Internal consistency and discriminant validity construct (AVE and squared correlation $\mathrm{n}=\mathbf{2 0 0}$ ).

Bootstrap re-sampling was performed to examine the statistical significance of path loadings in the molecular model and weights in the molar model. Table 4 show the results of the analysis. The path loadings and weights suggest the relative importance of each dimension. The results in Table 4 suggest that the path joining trust and perceived usefulness and cost and perceived usefulness were not statistically significant or validated.

\begin{tabular}{|l|l|l|}
\hline Path & Loading & T values \\
\hline CVN-PU & 0.216 & 2.9789 \\
\hline TRT-PU & $\mathbf{0 . 0 8 4}$ & $\mathbf{1 . 3 0 2 6}^{*}$ \\
\hline COST-PU & $\mathbf{- 0 . 0 1 8}$ & $\mathbf{0 . 3 7 1 9}^{*}$ \\
\hline PU-BI & 0.277 & 2,4405 \\
\hline PEOU-PU & 0.543 & 5.9303 \\
\hline PEOU-ATT & 0.358 & 4.1054 \\
\hline PU-ATT & 0.438 & 5.2064 \\
\hline ATT-BI & 0.367 & 3.7786 \\
\hline PU-BI & 0.277 & 2.4405 \\
\hline
\end{tabular}

*Paths not valid at $10 \%$ confidence

TABLE 4: The path, loading, and t-values for the construct Perceived Usefulness 


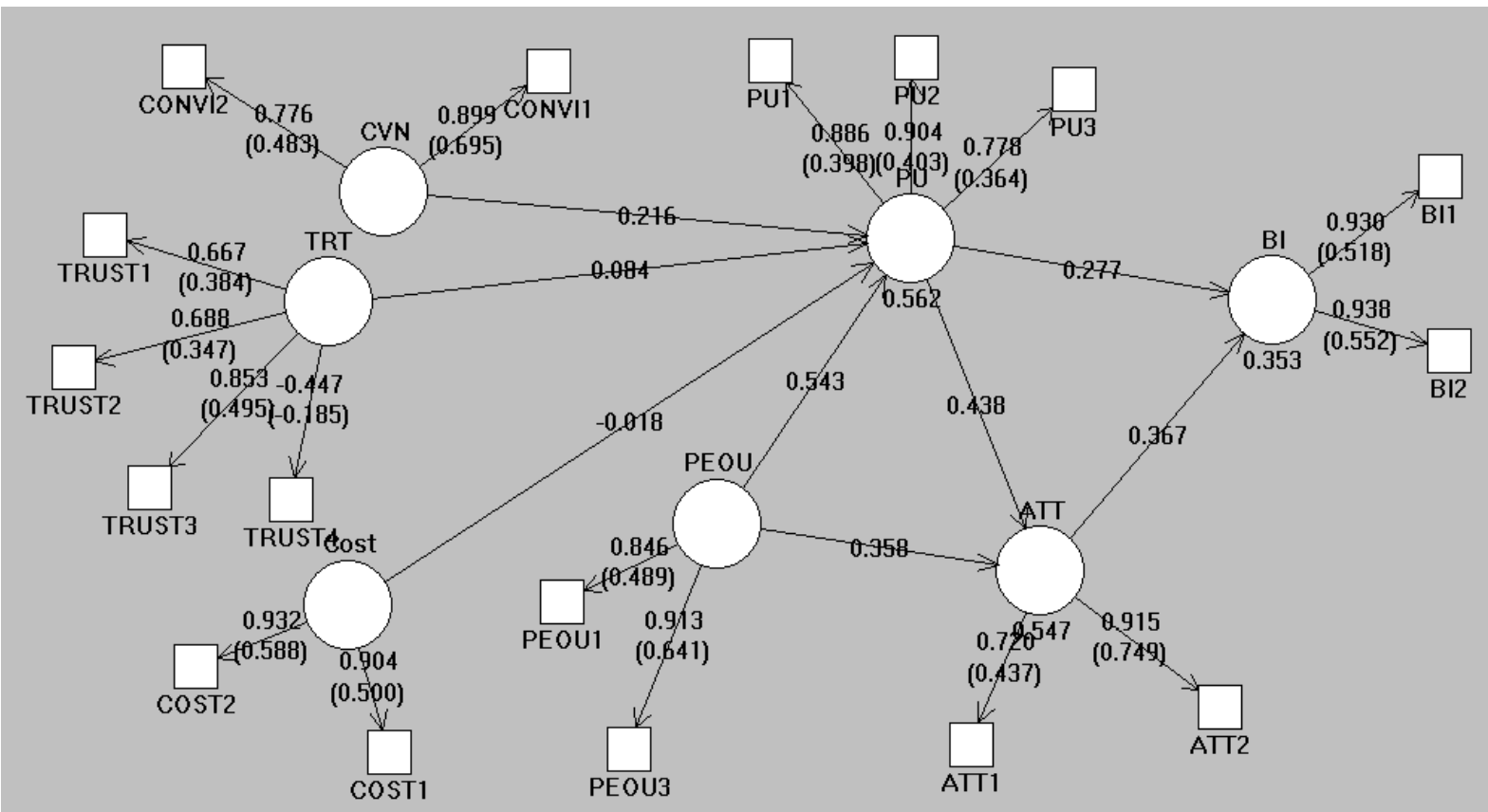

FIGURE 2: Molecular model for the paths and loadings

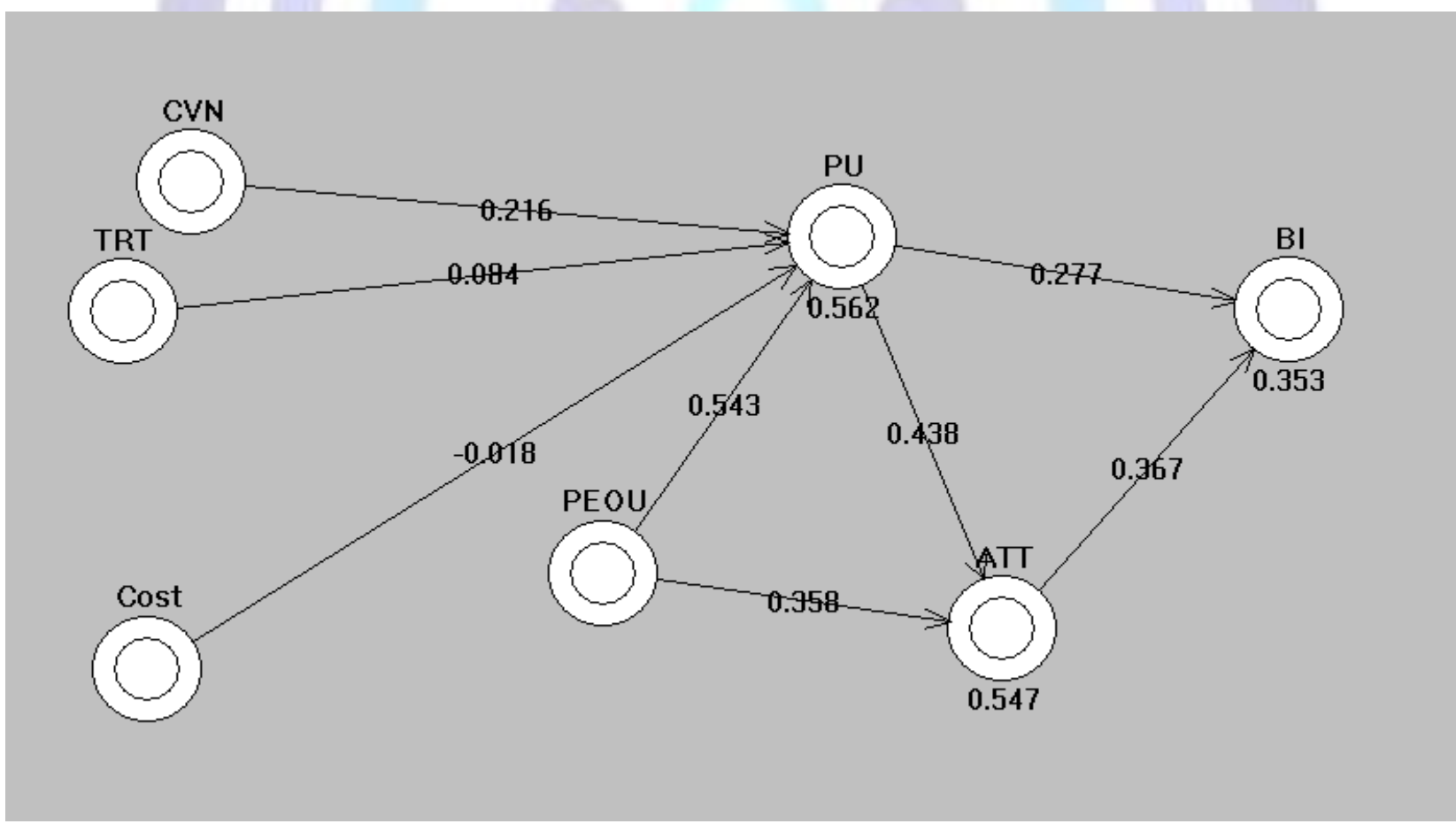

FIGURE 3: Molar model showing the paths weights

The model could not validate the path PU-Trust (TRT). This means that, contrary to the TAM model, particularly, the extended model as proposed by Luarn and Lin's could not validate the positive relationship between perceived usefulness and trust, including perceived usefulness and cost. 


\begin{tabular}{|l|l|l|l|}
\hline $\mathbf{H}$ & Hypothesis variables & Loading & Decision-accept or reject \\
\hline H1 & Perceived ease of use $\rightarrow$ Perceived usefulness & 0.543 & Accepted \\
\hline H2 & Perceived usefulness $\rightarrow$ Attitude & 0.438 & Accepted \\
\hline H3 & Perceived usefulness $\rightarrow$ Behavior intention & 0.277 & Accepted \\
\hline H4 & Perceived ease of use $\rightarrow$ Attitude & 0358 & Accepted \\
\hline H5 & Perceived usefulness $\rightarrow$ Convenience & 0.216 & Accepted \\
\hline H6 & Attitude $\rightarrow$ Behavior Intention & 0.3670 & Accepted \\
\hline H7 & Perceived usefulness $\rightarrow$ Cost/price & $-0.018^{*}$ & Not accepted/validated \\
\hline H8 & Perceived usefulness $\rightarrow$ Trust & $0.084^{*}$ & Not accepted/validated \\
\hline
\end{tabular}

\section{TABLE 5: Hypothesis testing and results}

Table 5 show the results of the hypothesis testing related to TAM model, $\mathrm{H} 1, \mathrm{H} 2, \mathrm{H} 3, \mathrm{H} 4, \mathrm{H} 5$ and $\mathrm{H} 6$ were validated and significant, while $\mathrm{H} 7$ and $\mathrm{H} 8$ could not be validated. The results show that the two external variables 'Trust' and 'Price/Cost' were not a good substantial and significant increase in the model predictability.

\section{Findings}

The demographic results reveal that the users of mobile banking are predominantly young black or African males who had a bank account and a cellular phone. The results further highlight that the majority of participants are married and, a large number of them have a diploma or a degree qualification. Mobile banking is mostly restricted to or dependent on a bank account and cellular phone.

The findings further reveal that Vodacom is the most popular choice for the use of mobile banking. The study concludes that most participants spend their money on airtime and and data bundles when doing mobile banking. Most of the participants use mobile banking for transferring and paying of beneficiaries, check mini-statements, buying prepaid airtime and obtaining account information. The study also concludes that most of the participants spend about 30 minutes connected when doing mobile banking.

The three variables namely, convenience, cost and trust, were added to the basic TAM model under "perceived useful" in order to do a broader investigations and obtain broader findings on the research topic. These results indicate that these three variables have extended the basic TAM model for the given data as shown in Table 5. The results further show that of the three variables convenience, trust and price or cost, only convenience was positively validated. Perceived usefulness and trust and perceived usefulness and cost could not validate the positive relationship between the two added constructs to the model (Hypotheses 7 and 8). This might be due to customers' concerns about the high cost of the use of mobile banking and the issue of trusting mobile banking (a risk of scams and phishing). Studies on this issue are inconclusive though.

Our conclusion is in line with the findings that if banks and other financial institutions wish to attract more customers to use mobile banking they should develop useful, convenient, affordable and trustable financial models or products for customers [42].

The study concludes by noting that for financial institutions to attract more customers, they should develop useful, convenient, affordable and trustable financial solutions or products that will be of high use by many customers.

\section{Discussion and implications}

The study's results support the findings of Berthon et al. [27] model to better understand the acceptance of mobile banking by individuals. The findings are consistent with the findings by Mathielson [45], Taylor \& Todd [46] and Luarn and Lin [25] who found that perceived usefulness influences customers' perceptions to use an information system (IS). The results showed that $67 \%$ of participants used mobile banking while $33 \%$ does not use mobile banking services. On the positive side, this means that banking institutions should try to do more marketing to attract more people to use this service. This could be through effective promotional campaigns with persuasive communication messages that aim at stimulating the usage of mobile banking.

The results indicate that customers' have an increasing interest in using mobile banking. Banks should therefore adopt a better communication strategy to attract and entice bankers to take advantage of mobile banking, noting its advantage of anywhere, anytime. This positive growth and interest by bankers to use mobile banking are contrary to the study done by Masinge [47], where only $30 \%$ of participants used mobile banking.

The results further indicate that trust played a critical role in adoption and influencing consumers to use mobile banking, taking into account the reliability of the system, trust-ability, quality, hacking of the system and scams. The results indicate that trust was found to be significantly negatively correlated to perceived usefulness. 
The results further reveal that perceived cost is a significant and influencing factor towards the adoption of mobile banking but cost remains a serious concern to many participants. This can also be seen as enabling resources needed for people to use mobile banking or online services namely skills, hardware, software, money, data and time. Therefore, bank managers should introduce cost effective services in order to attract, and encourage consumers' to use mobile banking. Many participants are worried about high financial costs and bank charges associated with mobile banking [44].

A revised pricing strategy should be introduced in order to reduce financial barriers facing potential consumers of mobile banking. This would assist banking institutions to attract more potential users of mobile banking. Central to the third variable, convenience has also been found my many researchers to have a pivotal role in the adoption of mobile banking. My analysis revealed that most participants are happy about the convenience of the system that can be flexible to be used anywhere, anytime. This therefore means banking managers should further improve this service so that it remains a competitive tool and advantage.

These study findings are in line with the findings by Pikksrainen et al., [33] who found that many customers think that doing business at branch takes too much time and effort. Convenience was found to be significantly positively correlated to perceived usefulness.

The findings of this study reinforce the findings on the analysis and the hypothesis that convenience is likely to influence $\mathrm{PU}$ on the adoption of mobile banking.

\section{AKNOWLEDGEMENTS:}

The authors express their gratitude to the anonymous referees whose comments have helped to improve the quality of this paper. The views expressed here are of the authors and not necessarily of the organisation they are associated with.

\section{REFERENCES}

[1] VENKATESH, V., MORRIS, M.G., DAVIS, G.B. \& DAVIS, F.D. 2003. User acceptance of information technology: Towards a unified view. MIS Quarterly 27(3) 425-478.

[2] BASA. 2012, 2011. Available from: www.co.za/wp-content/uploads/2013/07/BASA-Annual Report 2010-2011.pdf. [Accessed: 15/10/2013].

[3] MALLAT, N., ROSSI, M. \& TUUNAINEN, V.K. 2004. Mobile banking services. Communications of the ACM, 47: 42 46.

[4] SHIN, B. \& LEE, H. 2005. Ubiquitous computing-driven business models: A case of SK Telekom's financial services. Electronic Markets, 15:4-12.

[5] POUSTTCHI, K. \& SCHURIG, M. 2004. Assessment of today's mobile banking applications from the view of customer requirements. Proceedings of the $37^{\text {th }}$ Hawaii: International Conference on System Science. Hawaii.

[6] LUO, X., LI, X., ZHANG, J. \& SHIM, J. 2010. Examining multi-dimensional trust and multi-faceted risk in initial acceptance of emerging technologies: An empirical study of mobile banking services. Decision support systems, 49(2): 222-234.

[7] SIAU, K., \& SHEN, Z. 2003. Building customer trust in mobile commerce contributions of the ACM, 46(4): 91-94.

[8] LAUKKANEN, T. \& LAURONEN, J. 2005. Consumer value creation in mobile banking services, International Journal of Mobile Communications, 3(4):38-325.

[9] JARVENPAA, S., LANG, K.R., TAKEDA, Y. \& TUUNAINEN, V.K. 2003. Mobile commerce at crossroads: An international focus group study users of mobile handheld devices and service. Communications, ACM, 46(12):4-41.

[10] TIWARI, R., BUSE, S. \& HERSTATT, C. 2007. Mobile services in banking sector: The role of innovative business solutions in generating competitive advantage. Proceedings of the $8^{\text {th }}$ International Research Conference on Quality, Innovation and Knowledge Management. New Delhi, 11-14.

[11] KANNIAINEN, L. 2010. Alternatives for banks to offer secure mobile payments. International Journal of Bank Marketing, 28(5): 44-433.

[12] JANE, M.K., HOGARTH, J.M \& HILGERT, M.A. 2004. The adoption of electronic banking technologies by US consumers. International Journal of Bank Marketing, 22(4):238-259.

[13] KIM, G., SHIN, B., \& LEE, H.G. 2009. Understanding dynamic between initial trust and usage intentions of mobile banking. Information Systems. Journal; 19(3): 283-311.

[14] ROGERS, E.M. 2003. Diffusion of Innovations. ( $5^{\text {th }}$ ed). The Free Press, New York.

[15] LAUKKANEN, T. 2007. Internet VS Mobile banking: comparing customer value perceptions. Business Process Management Journal, 13(6):97-788.

[16] CRUZ, P., LAUKKANEN, T., MUNOZ-GALLEGO, P. 2009. Exploring the factors behind the resistance to mobile banking in Portugal, International Journal of E-services and Mobile Applications, 1(4): 16-35. 
[17] RAM, S. \& SHETH, J. 1989. Consumer resistance to innovations: the marketing problem and its solutions, The Journal of Consumer Marketing, 6(2): 5-14.

[18] BHATTACHERJEE, A. 2002. Individual trust in online firms: scale development and initial test, Journal of Management and Information Systems, 19(1):91-108.

[19] MUKHERJEE, A. \& NATH, P. 2003. A model of trust in online relationship banking. International Journal of Bank Marketing, 21(1):5-15.

[20] ALADWANI, A.M., 2001. Online banking: a field study of drivers, development challenges, and expectations. International Journal of Information Management, 21(3):25-213.

[21] SUORANTA, M. 2003. Adoption of mobile banking in Finland. Doctoral thesis, Jyväskylä, Finland.

[22] HOWCROFT, B., HAMILTON, R. \& HEWER, P. 2002. Consumer attitude and the usage and adoption of homebased banking in the United Kingdom. International Journal of Bank Marketing, 20(30):21-111.

[23] SATHYE, M. 1999. Adoption of internet banking by Australian consumers: An empirical investigation, International Journal of Business Marketing, 17(7):5-30.

[24] MEUTER, M.L., OSTROM, A.L., ROUNDTREE, R.I. and BITNER, M.J. 2000. Self-service technologies understanding customer satisfaction with technology-based service encounters, Journal of Marketing, 64(3):50-64.

[25] MICK, D.G. \& FOURNIER, S. 1998. Paradoxes of technology: consumer cognizance, emotions, and coping strategies, Journal of Consumer Research, 25(2):43-123

[26] DAVIS, F.D., BAGOZZI, R. P. \& WARTHAW, P. R. 1989. User acceptance of computer technology: a comparison of two theoretical models. Journal of Management Science, 35(8):982-1001.

[27] LUARN, P. \& LIN, H. 2005. Toward an understanding of the behavioural intention to use mobile banking. Computers in Human Behaviour, 21(6):91.873-891.

[28] DAVIS, F.D. 1989. Perceived usefulness, perceived ease of use, and user acceptance of information technology. MIS Quarterly Journal, 13(3):39-320..

[29] LEE, M. 2009. Factors influencing the adoption of internet banking: an integration of TAM and TPB with perceived risk and perceived benefit. Electronic Commerce Research and Applications, 8(3): 130-141.

[30] VENKATESH, V. \& DAVIS, F.D. 2000. A theoretical extension of the Technology Acceptance Model: Four longitudinal field studies. Management Science, 46:186-204.

[31] YANG, K. 2007. Individual social capital and its measurement in social survey. Survey Research Method, 1(1): 1927.

[32] VENKATESH, V. 2000. Determinants of perceived ease of use: Integrating control, intrinsic motivation, and emotion into the technology acceptance model. Information Systems Research, 11(4): 342-365.

[33] PIKKARAINEN, T., PIKKARAINEN, K, KARJALUOTO, H. \& PAHNILA, S. 2004. Consumer acceptance of online banking: An extension of the Technology Acceptance Model, Internet Research, 14(3),:224-235.

[34] GEFEN, D., KARAHANNA, E., \& STRAUB, D.W. 2003. Trust and TAM in online shopping: an integrated model. MIS Quarterly, 27, 51-90.

[35] GU, J., LEE, S. \& SUH, Y. 2009. 'Determinants of behavioural intention to mobile banking', expert systems with Applications, 36,(9):11605-11616.

[36] WALKER, M.F. 2004. Factors affecting the adoption of mobile banking service in retail bank South Africa. (Unpublished master's dissertation) University of Pretoria (GIBS) South Africa.p519.

[37] JAYAWARDHENA, C. \& FOLEY, P. 1998. Overcoming constraints on electronic commerce-internet payment systems. Journal of General Management, 24(2): 19-35.

[38] KARJALUOTO, H., MATTILA, M., PENTO, T. 2002. Factors underlying attitudes formation towards online banking in Finland. International Journal of Bank Marketing, 20 (6):261-272.

[39] KIM, M., CHUNG, N. \& LEE, C. 2010. The effect of perceived trust on electronic commerce: Shopping online for tourism products and services in South Korea. Tourism Management, In Press, Corrected Proof doi:10.1016/j.tourman.2010.01.011.

[40] GRAZIOLI, S. \& JAVENPAA, S.L. 2000. Perils of Internet fraud: An empirical investigation of deception and trust with experienced Internet consumers. Systems and Humans, 30: 395-410.

[41] GEFEN, D., STRAUS, D.W., \& BOUDREAU, M.C. 2000. Structural equation modelling and regression: guidelines for research practice, Communications of the Association for Information System, 4(7):1-79.

[42] WANG, Y., WANG, Y.M., LIN, H. \& TANG, T.I.2003. Determinants of user acceptance of internet banking: An empirical study. International Journal of Service Industry Management, 14:501-519. 
[43] MATHIELSON, K., PEACOCK, E. \& CHIN, W.W. 2001. Extending the technology acceptance model: The influence of perceived user resources. Database for advances in Information Systems, 32: 86-112.

[45] MATHIELSON, K. 1991. Predicting user intentions: comparing the technology acceptance model with the theory of planned behaviour. Information Systems Research, 2: 173-191.

[46] TAYLOR, S. \& TODD, P. 1995. Understanding Information Technology usage: A test of competing models, Information Systems Research, 6(2): 154-155.

[47] MASINGE, K. 2010. Factors influencing the adoption of mobile banking services at the bottom of the pyramid in South Africa. University of Pretoria (GIBS), South Africa.

[44] WU, J. \& WANG, S. 2005. What drives mobile commerce? An empirical evaluation of the revised technology acceptance model. Information \& Management, 719-729. 